\title{
ОСНОВНИ ЈЕЗИЧКО-СТИЛСКИ ПОСТУПЦИ У ДРАМИ КЛАУСТРОФОБИЧНА КОМЕДИЈА ДУШАНА КОВАЧЕВИЋА
}

У раду ће аналитичко-синтетичким приступом бити анализирани основни језичко-стилски поступци у драми Клаусиробобична комеgија Душана Ковачевића. У циљу да доследно представимо језичко-стилске доминанте драме, поља интересовања овог рада чиниће: а) питање пререгистрације и стилизације функционалних стилова, б) говорна карактеризација ликова на примеру драмског дискурса (дијалог, монолог, ћутња), в) специфичност дидаскалија, стилогена вредност наративизације у драмском следу, г) антитетична и екстратекстуална стилистичка својства на примеру драме Клаустирофобична комеgија.

Кључне речи: Душан Ковачевић, Клаустирофобична комеguја, драма, дијалог, лингвостилистика, драмски поступци, дидаскалије.

\section{1. Књижевноуметнички стил и разговорни језик - стилизација и пререгистрација}

Драму Клаустирофобична комеgија Душан Ковачевић написао је 1987. године у Београду. Сачинивши причу о „узалудним" животима појединаца који постају архетип угњетаваних људи на прагу нове идеологије, где стари систем још увек маскиран бди, суочили смо се са драмом савременог доба и језичко-стилским специфичностима које оно доноси. Припадајући по класификацији књижевноуметничком 
стилу и драмском подтипу, драма Клаустирофобична комеguja садржи све законитости које поменути стил чине. Међутим, драма у којој преовлађују дијалогичност и конверзација, али и наратизовани и ауторски говор у дидаскалијама и коментарима, доводи до проблемског питања стилизације и пререгистрације драмског и разговорног језика.

Питањем пререгистрације у књижевноуметничком функционалном стилу бавила се Марина Катнић Бакаршић (в. избор литературе), а у овом раду тај термин користимо сматрајући га погодним за приказ неких особености драмског текста. Пререіистирација је јеgинстивени йостиуиак књижевноуметиничкоі стиила који је сйособан gа у себе инкорйорира

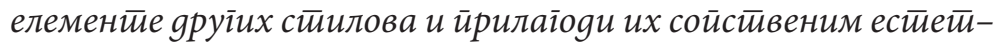
ским иилевима, закључује Бакаршићева (Катнић Бакаршић 2013: 43). Творећи драму у којој су једнаким интензитетом присутни дијалог, монолог, дидаскалије и наратизовани коментари, указује да смо сведоци јединствене целине у којој је поливалентност важна карактеристика. Поливалентност је почетна смерница која ће постати важно обележје стваралаштва Душана Ковачевића како у погледу поливалентности жанрова, тако и у разумевању језичко-стилских поступака. Међутим, читајући драму Клаустирофобична комеgија можемо запазити поступке инкорпорирања разговорног функционалног стила у књижевноуметнички текст са којим твори јединствену целину. Дијалози између Веселе Крај и брата јој Јагоше Краја указују на особине разговорног језика. Присутни су: елиптичност, оклевање, упадање у реч, нагла промена тема, фатичка комуникација, спонтаност, поштапалице. Међутим, да остајемо у границама драмског дијалога доказује чињеница да драмски израз има циљ, а драма оправдава запажање Дејвида Кристала да је то у ствари gujaлог̄ у акиији (Кристал 1994: 75). Неминовна тежња аутора да у појединим сегментима драме артифицијелни дијалог приближи свакодневном одлика је савремене драме, али и метод сликања ликова. Говорна карактеризација, о чему ће бити речи у наредном поглављу рада, неизбежно учествује у креирању поступака ликова и њихових особина. У говору Веселе Крај у драми Клауситрофобична комеgија има више 
ћутње него дијалога. Покоји дијалог с осталим актерима драме извесно указује на њен подређени положај, (не)заинтересованост и индиспонираност. Стога, уз поступак пререгистрације елементи разговорног дијалога бивају стилски одсликани у говору Веселе Крај и помажу у тумачењу традиционалних структуралистичких питања. Пример напоменутом биће телефонски разговор између Веселе и Јагоше, где чујемо један глас, а други наслућујемо, што представља репрезентативни приказ пререгистрације:

ВЕСЕЛА: Здраво, бато... Никако... Ево, баш те сад помињемо... Ма свађам се с овим нашим несрећним братом. Шта бих ја друго радила!... Убеђује ме да си малопре био овде. Начисто је пошашавио... Први пут кад ме убеди, ти нећеш имати никог нормалног... Да... Шта? Да скинем црнину за мајком... Ја је сад носим за собом. Ни мене одавно нема... Шта ти радиш, бато? Идеш у позориште? Гледаћеш пољски балет... Ойела... Лепо, лепо... Немој само опет да се жениш балерином. И прошли пут си прво ишао да гледаш балет, па знаш како си се провео... Да ниси то што јеси, никада не би добио још један стан... Ако морам тебе да перем, не морам и те што дижу ноге... После представе, одмах кући... Синоћ сам те гледала на телевизији, у дневнику. Бато, пусти бркове. Изгледаш много млад за све те положаје. Што је већи положај, наш народ воли да види што старијег човека... (Ковачевић 2013: 103)

У жељи да појам стилизације $\mathrm{e}^{1}$ не одвојимо нужно од појма пререгистрације, већ да укажемо на њихове кохерентне и допуњујуће вредности у књижевноуметничком тексту - драми, истакли бисмо и стилизованост говора Вулета милиционера у Клаустирофобичној комеgији. О начину креирања дијалога и његовој функцији у карактеризацији лика

1 Стилизацију разумемо као метакреативни поступак који опонаша неку карактеристичну форму зарад уметничког ефекта, где прототекст постоји, а говорна карактеризација добива стилогену вредност. Више о томе в. Катнић Бакаршић (1999). 
ће бити речи, али специфични говор Вулета милиционера у драми нас упућује на језичку реализацију својствену говорном језику свакодневице. Међутим, за разлику Веселе Крај, он својим говором показује неснађеност, неукост, инфериорност, те у дијалогу са Савом Оџачаром запажамо карактеристике говорног стила:

МИЛИЦИОНЕР: Хм... Као да је неко кинуо... Лепо сам чуо... неко је кинуо... Као дете.

CABA: Ено... мачка побеже.

МИЛИЦИОНЕР: Мачке кијају?

САВА: Чуо сам кад мачке плачу као деца. Тако и кијају... Теби је мало криво што видиш да скупљам хлеб.

МИЛИЦИОНЕР: Јесте... И да знаш, има да ти помогнем. Ако си ти мени... кад ми је у животу било најтеже... САВА: Хвала, Вуле.

МИЛИЦИОНЕР: Има... да пређеш... да радиш код мене. CABA: Матор сам ја за ту униформу.

МИЛИЦИОНЕР: Као магационер... Нећеш ти мени да прекопаваш туђе ђубре.

(Ковачевић 2013: 110)

Постављајући питање да ли поменути аспекти употребе језика на претходним примерима дају драми статус уметничког (Ковачевић 2015: 7), долазимо и до закључка да поступци пререгистрације и стилизације разговорног језика који су прилагођени књижевноуметничком стилу указују на уметничку вредност драмског дијалога у употреби чинећи како жанровску ${ }^{2}$ тако и језичко-стилску поливалентност.

\section{1. Дијалог}

У жељи да стилистичку анализу драмског дискурса Клауситрофобичне комеgије не сведемо само на проучавање

2 О жанровској поливалентности у драми Клаустиробобична комеgија Душана Ковачевића в. Живковић (2011), Кебара (2019), Христић (2006). 
фрагмената и микроелеманата, потрудићемо се да, својствено савременим теоријама, представимо језичке и ванјезичке вредности, а не запостављајући и традиционална питања о варирању говора, употреби дидаскалија, интертекстуалности. Говорна карактеризација ликова на примеру поменуте драме ослања се на дијалог. Дијалог као основна форма драмског дискурса у овом случају кореспондира са једнако вредним монологом и ћутњом, а све са циљем остваривања естетских вредности књижевноуметничког текста.

Специфичност дијалога у драми Клаустирофобична комеgија можемо тумачити на основу следећих критеријума:

a) однос доминантних и споредних ликова - моћ у дијалогу,

в) језичка функција која се остварује дијалогом. ${ }^{3}$

А) Однос доминантих и споредних ликова у чијем се дијалогу одсликава моћ у комуникацији најбоље можемо запазити у конверзацији Јагоше Краја с осталим јунацима ове црне комедије. Јагоша, истакнути политички функционер који чини све зарад свеопште „добробити”, па чак и жртвује рођеног брата зарад „виших” циљева, представља лик у чијем говору и односу према другима запажамо изузетну неемпатичност и саможивост. Према начелима кооперативности Грајса, који истиче да непоштовање максима ${ }^{4}$ нарушава могућност успешне комуникације, у говору Јагоше Краја запажамо непоштовање свих наведених максима, а посебно нарушавање максиме модалитета коју Бакаршићева и назива стиилистиччка максима (Катнић Бакаршић 2013: 107). Двосмислено, опширно излагање, избегавање истине, непоштовање саговорника указују на карактеризацију лика који има моћ и злоупотребљава је. Један од примера јесте дијалог Саве Оџачара и Јагоша Краја када споредни лик

3 Више о теоријској основи именованих критеријума в. Катнић Бакаршић (2013). Важно је напоменути да критеријуми на основу којих се заснива интерпретација дијалога у драмском тексту нису искључиви, већ имају и допуњујућу вредност у анализи. Разврстани су у циљу да се створи конзистентна интерпретативна целина.

4 Грајс изводи пет максима чије поштовање води ка успешној комуникацији, а то су: максима квантитета, квалитета, релевантности, модалитета и учтивости. Више о томе в. Катнић Бакаршић (2013). 
- Сава Оџачар покушава да приволи Јагошу за помоћ у решавању случаја пољске балерине:

САВА: Комшија, овако вас молим, помозите ми... помозите нам... помозите јој...

ЈАГОША: Шта да Ти Вам Јој помогнем?

САВА: Извињавам се, изгледа да сам... да смо дошли у незгодно време.

JАГОША: Журим. Реците.

САВА: Па, ја бих те... вас молио...

JАГОША: Ова под ћебетом је нека уметница?

САВА: Велика уметница! Она је...

ЈАГОША: Светска уметница?

САВА: Светска, баш светска.

JАГОША: Знао сам. Чим сам је угледао овако под ћебеTOM.

САВА: Она је...

ЈАГОША: Има ли неко у овој земљи ко није светски уметник? Написао две песме, хоће стан - светски песник! Написао пола приче, другу половину ће - чим се усели! Нацртао зеца, хоће атеље - светски сликар. Па нисам ја, комшија, мултинационална грађевинска компанија за збрињавање светских луда. „Светски уметници” да се обрате свету, ја сам задужен за обичне и нормалне људе. Без крова зидари, ливци, рудари. Радничка класа на власти и на улици.

(Ковачевић 2013: 150)

Из наведеног одломка запажамо изузетно поштовање максиме учтивости у говору инфериорног лика - Саве Оџачара, који добија обрисе снисходљивости са циљем да оствари своју молбу. Међутим, кроз доминантног лика сусрећемо се с одликама прагматичког дијалога ${ }^{5}$ у функцији

5 Прагматички дијалог одликује неравноправни однос учесника (споредни и доминантни), али и размену информација и услуга. Сличан је свакодневној комуникацији (Катнић Бакаршић 2013: 139), што може бити основ за пререгистрацију и инкорпорирање разговорног функционалног стила у књижевноуметнички. 
карактеризације и доследног сликања деградације уметности и дехуманизованог опхођења. Сукоб браће Јагоше и Теје Краја темељи се на различитим погледима друштвено-политичке стварности, различитим припадностима и принципима и стога се и њихов дијалог током целе драме заснива на конфликту који кулминира метафоричним сукобом идеологије и човека, где човек бива жртвован зарад „виших” принципа и проглашен лудим у свету лудака. Вантекстовни елементи утичу на конфликт међу браћом, а иронија и сарказам воде до

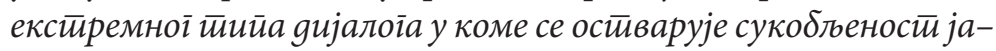
$\bar{u}$ и са емоционалним набојем (Мукаржовски 1986: 110):

TEJA: Јеси ли „Књижевне новине” читао приватно или службено?

JАГОША: Мислиш, да ли као љубитељ уметности или као љубитељ власти? Читао сам их приватно, најприватније.

TEJA: Па шта ти се не свиди, ти нападнеш службено, најслужбеније.

ЈАГОША: Ја нисам песник да вам на песме одговарам песмицама.

TEJA: Па одговараш песницама.

(Ковачевић 2013: 95)

Б) Дијалози који у драмском тексту представљају реализацију језичких функција посебно су драгоцени за језичко-стилску анализу драме Клаусширофобична комеgија. Дијалог Вулета милиционера и Саве Оџачара у седмој сцени другог дела драме указује нам на експресивну језичку функцију чија се стилогеност запажа у реторичним монолозима, а чини је прича о дивљем вепру који је Вулету милиционеру спасао живот. У поменутој сцени сусрећемо се са карактеризацијом лика Вулета милиционера чији је говор попут разговорног језика, пун поштапалица, понављања и несигурности, а у функцији дочаравања мотива одрођености ${ }^{6}$ у драми Клаустиробобична комеgија:

6 Више о мотиву одрођености у драми Клаустирофобична комеgија в. Лончар (2017). 
САВА: Били сте припити?

МИЛИЦИОНЕР: Чуј... припити... Не би се ни ја спасо да се не ухватих за дивљег вепра који је препливао реку... Спасо ме створ кога сам пошо да убијем.

(Ковачевић 2013: 135)

Естетска (поетска) функција представља gоминанйну оgлику gрамскоі йекстиа на макройлану (Катнић Бакаршић 2013: 84), а у драми Клаустирофобична комеgија можемо је запазити у дијалогу Саве Оџачара и пољске балерине Нине Херберт. У њиховом случају актери дијалога нису свесни естетске вредности коју њихов израз носи, а то се нарочито види у говору Саве Оџачара. Уплив пољског језика, о чему ће више бити речи у наредном поглављу, није омео Саву Оџачара да ову црну комедију уздигне до елемената мелодрамског стварајући катарзичну атмосферу у црном свету са трагичним крајем:

САВА: Јесте, виолина је - виолина... али клавир је - клавир... Да сам имао среће у животу, да ми је неко омогућио бољи живот - као што није, па ме питао: „А којим би се ти инструментом, Саво, служио?” Ја би' рек'о: „Клавир”. Клавир, „Баш клавир?” „Баш клавир... Ни виолина, ни хармоника... Не знам зашто.” Можда све због једног руског филма, који сам гледао као дете... У том филму је један дечак свирао клавир тако мален као што сам ја био; горео је камин, господа су слушала, пила шампањац и плакала... А кроз прозор, завејан великим руским снегом, вирила је мала, сирота сестра дечака за клавиром. Дечак је ујутру добио десет дуката, а сестру су нашли смрзнуту у снегу, испод прозора... Дечак је после постао велики композитор. И никад није хтео више да свира господи, а све своје ноте посветио успомени на сестру Вању... Кад смо изашли из биоскопа, на улици је вејао снег, а ми смо плакали... Увек кад чујем клавир - сетим се тог филма... Да ли је могуће, Нина, да сам те зимске вечери заволео клавир... Може бити... Човек обично не зна кад нешто или некога заволи за цео 
живот. Сазна тек много касније, кад нечега или некога више нема.

(Ковачевић 2013: 116)

\section{2. Монолог}

Монолог у драми Клаустирофобична комеgија можемо посматрати кроз лик Теје Краја. Према Пфистеровој подели на акционе и неакционе монологе (Пфистер 1998: 2007), Тејине монологе разумемо као неакционе, јер покрећу мисли, а не радњу и йурнуси $\bar{\tau}^{7}$ бвају gуже рейлике које gобијају особине филозофскої монолоїа. Док је за лик Јаїоме Краја везан

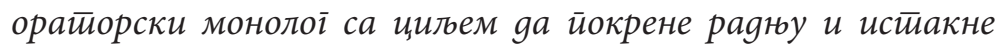
моћ, Теја Крај је суйроитна сиирана йородичне ӣраве. Он је јунак-ияеја у овој ярами, који йвори драму у ярами и йосй-

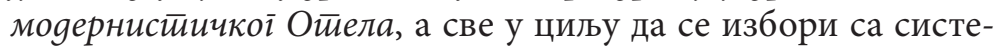
мом - владајућом идеологијом. Његова борба бива узалудна и чини да ова црна комедија поприми нијасе још тамнијег. Кроз Тејин лик видимо савременог Јозефа К, Дона Кихота, Хамлета и Отела, који су заглављени у држави. Његове дуже реплике које можемо разумети као јединствене монологе, указују да је Теја Крај лик-идеја у овој драми и служе психолошкој карактеризацији. Док кроз дуже реплике Вулета милиционера опажамо и његов унутрашњи свет, носталгију за домовином и емоције, неукост, приземност, али и искреност и патњу, кроз дуже турнусе Теје Краја видимо не само унутрашња превирања већ и идеју за спасом намењену како јунацима драме тако и читатељима, гледаоцима. Теја Крај, босоноги преводилац Шекспира, покушао је уметношћу да се избори са црном реалношћу, али узалудно - проглашен је лудаком у свету лудих:

TEJA: Видите, господине Грабињски, у нашем комшилуку живе јадни, сироти и несрећни људи, исти они за

7 Турнус је реплика саговорника која следи или претходи реплици другог саговорника. Дужи турнуси једног саговорника се могу разумети као монолози (Катнић Бакаршић 2013: 56). 
које имамо велико разумевање док о њима читамо као о јунацима добре литературе. Кад склопимо странице књига, покушајмо да их разумемо - да им помогнемо, док не закораче у свет уметности. Ако бисмо то учинили, можда би било мање добрих књига али сигурно и мање несрећних људи.

(Ковачевић 2013: 158)

Пример дужег турнуса (који има особине монолога и у функцији је карактеризације Јагоше Краја) видимо на почетку драме у, наизглед, разговору а заправо монологу који Теја води пред сестром Веселом:

TEJA: Јеси га чула, Весела? И да знаш, није крив само он што је овакав. Може да захвали сиротој мајци што је постао „успешан” политичар. Од најранијег детињства све његове грешке и кривице преузимала је на себе, дозвољавала му је да лаже колико хоће, поносила се и кад је причао будалаштине, није јела да би он имао две порције - па је мислио да живимо у изобиљу. [...] Растао је у свету који ничим није заслуживао, па се навикао и тако данас живи. Сирота мајка је живела двадесет година краће да би он живео двадесет година дуже.

(Ковачевић 2013: 101)

\section{3. Ћутња}

Ћутња и пауза у драми Клаустирофобична комеgија имају стилску маркираност и посебно су везане за лик Веселе Крај. Наизглед, јунакиња која слабо говори и мисли, постоји на сцени у црнини и не йостиаје тище у Тејиној gрами

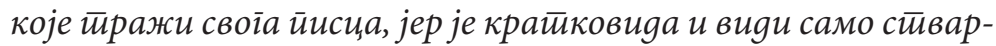

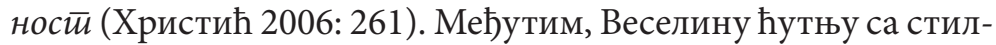
ског аспекта можемо тумачити као одсуство говора чији циљ може бити приказ прекора, љутње, самоће, немоћи. Прави приказ клаустрофобије из наслова драме можемо пронаћи у тишини Веселе Крај, чије име и презиме указују 
на антитетична својства, стилски маркирана, о којима ће бити речи. Чак и када Весела, говори запажамо карактеристике фатичког дијалога, разговорног функционалног стила, али не као приказ неукости, већ немогућности да се изрази. Веселину тишину можемо разумети као начин борбе у клаустрофобичном систему који изједа изнутра. Она се налази између два брата опречних ставова, на средини и са немогућношћу да помогне и спаси себе и њих.

За разлику од Веселе Крај, крајња ћутња Саве Оџачара упозорава нас на страдање уметности и вредности у свету комунизма, односно социјализма, који руши човека у потпуности. Иако је оџачар, из жеље да помогне свима, упознао нас је с истинском лепотом и обрисима ларпурлатизма. Тиме се остварује стилска маркираност у карактеризацији лика, а себи је „помогао” самоубиством, последњим криком који води у крајњу тишину, а чију атмосферу приказује претпоследња сцена:

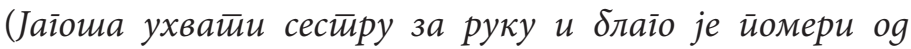
Савиноі узітлавль. Оgвоgи је... Неїgе из ходника gойире юен хисиерични йлач. Сава йомера руке. Ойвара очи. С найором дохватии крај цевчице, йри gну боце, ойусиии руку на којој је ирривезана Нинина марамица и ирекияе оgвоg крви. Рука клону йокрај креветиа, а из ирекинуйе иец,вчие крв йрокайа на йоg. Друїом руком скияе маску за кисеоник. Пискави звук елекитрокарgиоірама йоче gа

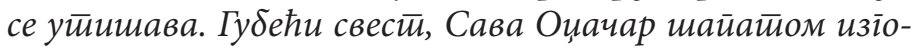
вори.)

САВА: Нина... Нина... Нина...

(Ковачевић 2013: 163)

\section{1. Дидаскалије и наративизација}

Дидаскалије у драми Клаустирофобична комеgија имају стилогену вредност зато што су наратизоване, носе естетску, информатичку и референцијалну поруку. Кроз поступак наративизације Душан Ковачевић је у драмски дискурс увео 
елементе прозног жанра, што доприноси слици поливалентности текста. Друга сцена у драми - Балерина Нина Херберй нестиаје са сиене Нарояноі йозоришйа у тику Дездемоне, написана је цела у дидаскалијама, а у функцији је приказа дешавања драме у драми и стварања метатеатралног ефекта где имамо утисак као да читамо кратку прозну причу и стога синтаксичке црте у драми нису јединствене. Уводна дидаскалија пример је наратизоване дидаскалије у функцији карактеризације ликова својствене прозном жанру а, опет, садржи и синтаксу йозоришної језика и приповедачку синтаксу. Аутор нас је упознао с атмосфером драме и сликом разорене породице - нуклеуса у стваралаштву Душана Ковачевића који ће постати архетип људског страдања. На тој слици аутор гради своје guјалоїе у акцији, чиме твори јединствени спој прозног и драмског, а ипак правећи разлику:

Теја Крај сеgи за кухиғским сииолом, йо коме су расиростирие разлистиане кюиіе и рукойиси. Сувонав, разбарушен, необријан (иррофесор енілескоі језика без йосла, иреводитаи за своју gушу), йрекрстиио је босе ноіе исйоg

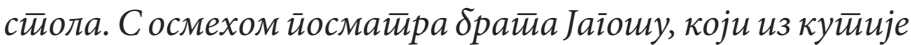
ваgи нову, белу кошуљу. Брай је йо іодинама стиарији а йо изілеgу млађи. Теја иррияржава ілаву шакама као уснули иууйник на железничкој стианиии. У уілуу собичка, на ситолиии без наслона, сеgи крайковияа сестира Весела, иижнна девојка, у ирнини за мајком и собом. Савила се наg животиом и Тејином чарайом коју ииийаво криии ирреко сијалиие. Уразі̄овору и свађи браће не учестивује ни йоілеgом - као gа их нема. Јаїоша ирреби иілице из кошуље,

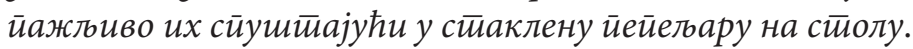
(Ковачевић 2013: 94)

Дидаскалије које имају естетску функцију са циљем да буду пратња репликама и метајезичка допуна при карактеризацији ликова могу се видети у сценама дијалога Саве Оџачара и пољске балерине Нине Херберт. 
(Он ирритичну gирку на ірамофону, ваљьgа с исиимм узбуђенем и оgіоворношћу као каg се иритиска gуіме за лансирате неке велике свемирске летелице. И мали, убоїи собичак обасја раскошна светилосй Чајковскої. Нина йосматира час ірамофон, час ирноі човека. Сава

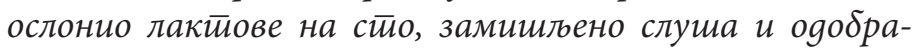
вајуће клима ілавом - као да је уіллеgао нейознатии іраg c врха йланине који му се на йрви йоїлеg свияео.)

(Ковачевић 2013: 115)

\section{2. Стихови у драми}

Тејина интерпретација Дучићевих ${ }^{8}$ стихова приликом шетње у припитом стању са йољским йријайељем йо йеваюу, иначе уваженим іосйом Дана кулитуре (Ковачевић 2013: 106), господином Грабињским, чини да уочимо стилске вредности увођења стихова у драмски след. Сложили бисмо се са мишљењем Марине Катнић Бакаршић да стихови могу бити предложак за песму (Катнић Бакаршић 2013: 38), а наставак Тејиног рецитовања и надградња песме то и доказује:

TEJA: И ґуббав шито чезне, и јеg шито се іннуша, Све је само иесма; gок мре у gубини Све у чуяну светилости обучена gуша Као звезgа шито се расйаgа у ймини. И док се у миру тика вечитио йкиво, Хуји ілас стивараньа и ритиам расула И док у йе сайе још стирасно и живо Све сазнају моја ойијена чула Ја знам gа несйајем у шуму шито блуgи Са сваким кораком којим ноїа крочи: Сйрана за йраву срећу и йрави бол љуgи Уйирући к небу зачуђене очи. И док земљом ходим у суморна gоба,

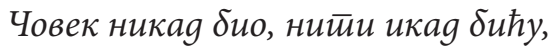

8 У питању је Дучићева песма „Песма” (Никаg не знам куg ће ова йесма $x \overline{\mathcal{u}} e \overline{\mathcal{u}} u)$, с тим што Теја Крај рецитује последње три строфе песме. 
Јеgан мали иесник, као сена роба

Данас вам се клана іеније Дучићу!

(Ковачевић 2013: 106)

Узимајући у обзир и вантекстовне елементе, социокултурни контекст, епоху и тренутак у ком се радња драме одвија и стигавши до појединачних ликова и њихових реплика, можемо претпоставити да су наведени стихови које Теја Крај рецитује у тренутку када је пољска балерина нестала, предложак за стварање постмодернистичког Ойела, његове драме у драми, а и изврсни крик безнађа у коме се уметник нашао. Стихови у драми неминовно имају естетску вредност и циљ може бити приказивање појединца у свету клаустрофобије, где песник опстаје над човеком зато што свеопшту бол може примити на себе. Хуји ілас сииварағьа и ритиам расула - стих је који може представити атмосферу читаве драме, а мајсторски сачињен спој поезије и прозе у драми са мотивима безнађа против кога се можемо борити смехом и пијанством - слика су друштва Клаустирофобичне комеgије. Аутопоетички коментар претворен у стихове представља директно, апострофично обраћање и има тон опомене у тренутку безнађа и заглављености у држави:

Еj, земљо моја, земъо найаћена,

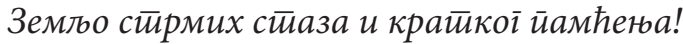
(Ковачевић 2013: 107)

\section{1. Антитетична стилистичка својства}

Специфична антитетична стилистичка својства у драми Клаусйрофобична комеgија Душана Ковачевића огледају су у жанровским специфичностима, именовању ликова, стварању вештачког језика који има лудичку функцију и постаје средство вербалне комике.

Наслов драме Клауситрофобична комеgија представља синтагматску конструкцију са стилогеном вредношћу, а у драмској функцији изневереног очекивања. Наиме, носилац 
значења у синтагми јесте атрибутски члан (клаустрофобична) и он упозорава на тескобну атмосферу драме и чини да у споју са главним чланом синтагме (комедија) увидимо обрисе саркастичног приказа црнила у даљем драмском следу, где смех служи привидној а не окрепљујућој борби у тоталитарном, нерешивом систему. Драма Клаустирофобична комеguја жанровски припада црнохуморној комедији, где се комично и озбиљно преплићу, творећи суморни комад о људским судбинама са изразитим антитетичним стилистичким својствима.

Такође, антитетичне спојеве с иронијским карактером запажамо и у именовању ликова и њиховој карактеризацији: Весела Крај - $\overline{ш ж ж н а ~ g е в о ј к а ~ у ~ и р н и н и ~ з а ~ м а ј к о м ~ и ~}$ собом (Ковачевић 2013: 94), апсурдни је приказ летаргичног и измученог лика чије је име Весела; презиме породице Крај стилски је маркирано и као да антиципира потпуну породичну, друштвену и политичку разореност, што и реплика Јагоше Краја приликом свађе са братом и иронично доказује:

JАГОША: Гадно, ето како! О другу Јагоши КРАЈУ. Наше презиме КРАЈ, поштено 400 година, користи се као ружан политички симбол... као крај свега... као... Ааaаa, стићи ће вама рачун за овај месец, па ће вам стварно бити - крај!

(Ковачевић 2013: 97)

Посебан поступак драмске стилизације јесте увођење измишљеног језика у реалне оквире са наизглед лудичком функцијом $^{9}$ и празним цитатима, али неминовним присуством метатекстуалности и вербалне комике. Пример у Клауситрофобичној комеgији јесте пета сцена са насловом Ко је Жан Унїа Бумані̄o? Шйа је? Ogaкле је? И - ige је йо? У питању је метафорични приказ диктаторске тортуре и начина владања који провејава драмама Душана Ковачевића, постајући манир. Наизглед да све делује једноставно, реално

9 Лудички дијалог има примарну функцију игру, врши се поигравање са лексичким изразом и конверзацијом и има естетске карактеристике (Катнић Бакаршић 2013: 148). 
и јасно, а опет искривљено - мајсторски је поступак грађења приче где се све каже, а опет ништа, спој трагедије и комедије у једном:

CABA: То је онај мали, кривоноги, позлаћени кепец, кога су по Београду звали „Хајл Дукат”. С ким год се руковао, дао му је дукат са својим ликом.

ЈАГОША: Људи који нас посећују доносе своје обичаје и своју културу.

CABA: И народно злато. Неки тамо, међу оним несрећницима умиру од глади, по ваздан бере памук и банане, на плус хиљаду степени, неко тамо по ваздан црнчи, као што ја овде црнчим, да би његов председник, у његово име, без његовог одобрења, делио по свету његову крв и зној. Ружан лик на златном зноју. А постао је политичар само због свог жалосног раста. Био је превисок за циркус а премали за живот... Озлоглашени диктатор и разбојник.

JАГОША: Тачно, комшија, али смо све то касније сазнали.

CABA: Чеси, па ми? Шта би иначе био човек који по свету дели народно злато без знања и питања свога народа? Како ви називате човека који нема ништа своје а све је његово?

(Ковачевић 2013: 121)

Увођење страног језика у драму, које је у Клауситробобичној комеgији представљено кроз лик пољске балерине Нине Херберт, представља стилску и идеолошку маркираност у тексту. Смењивање пољског, енглеског и француског језика посебну естетску вредност добија у дијалогу Саве Оџачара и Нине Херберт, а разлог лежи у томе што Сава не зна ниједан од три поменута језика, али се на најбољи начин споразумева са пољском балерином у односу на остале актере. Дијалози у ком се смењују српски и пољски језик превасходно утичу на говорну карактеризацију Саве Оџачара и у функцији су поетских вредности књижевноуметничког текста. И Сава Оџачар истиче да је са Нином 
разговарао врло йажљиио, што је доказ да некада речи нису потребне да би се међусобно разумевање и препознавање догодило.

\section{2. Екстратекстуална стилистичка својства}

Екстратекстуалност у драми Клаусӣрофобична комеguja проналазимо у метатекстуалним и метатеатралним коментарима, значењу поднаслова, али и интертекстуалном грађењу драме у драми.

Цитатност, интертекстуалност, метатеатралност поступци су карактеристични за драму постмодерне и стилско обележје драме Клаусйрофобична комеgија Душана Ковачевића. Стварајући причу о савременом Отелу, Теја Крај прави јединствену драму у драми, чиме оправдава оно што

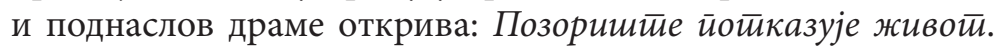
Међутим, цитатност у драми Клаусіирофобична комеgија разумемо кроз Лотманово виђење да исти сегмент употребљен у два текста није исти, већ се преношењем цитата из прототекста у метатекст, усложњава мрежа значења. Такође, Данило Киш у Часу анайомије наводи да цитат из једног текста инкорпориран у други текст носи ново значење, што драма Клауситрофобична комеgија и потврђује. Сложивиши се са тумачењима да Теја ствара йостимоgер-

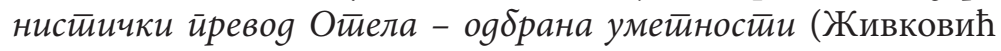
2011: 194), додали бисмо и став да кроз питање уметности и ларпурлатизма у драми Клаусиирофобична комеgија упознајемо новог Отела кроз различите форме, али заробљеног не у љубомори, већ у држави, потчињеног идеологији у којој се циркуларно креће док не нестане. Кроз интертекстуалност и метатеатралност у драми Душана Ковачевића остварује се интеркултурна повезаност и шире поље тумачења где интердисциплинарни модел употпуњује стилистичку ана-

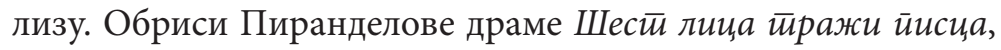
Чеховљеве драме Галеб и Нушићеве Кюиіа gруїа, драгоцен су подстицај за детаљнију анализу и могући предмет интересовања неког новог тумачења. А у складу са вредностима 
аутопоетичких коментара у драми Клаустирофобична комеguja, тумачење бисмо завршили и последњом реченицом из драме: Биће ваљьяа јеgном (Ковачевић 2013:163).

\section{Закључак}

У раду је аналитичко-синтетичким приступом приказана језичко-стилска анализа драме Клауситрофобична комеguja Душана Ковачевића. Са циљем да задовољимо потребе и традиционалне структуралне стилистике и савремене стилистике, анализи смо приступили вишеаспекатски. Основна поља интересовања овог рада чиниле су четири целине:

питање пререгистрације и стилизације драмског текста, говорна карактеризација на примеру драмског дискурса сводила се на анализу дијалога (врсте дијалога, функција и циљеви), монолога и ћутње,

специфичност дидаскалија и стилогена вредност наратизованих делова,

антитетична и екстратекстуална стилистичка својства у драми Клауситрофобична комеgија.

На основу наведених целина дошли смо до закључка да је драма Клаустирофобична комеgија Душана Ковачевића пример дела с изразитим поливалентним својствима која се тичу и жанра, али и језика и стила. Ослањајући се на тезу Дејвида Кристала да је gрама guјалоі у акиији, суочили смо се са драмом у којој наратизовани и стилски обојени делови представљају основ за развој таквог дијалога. Естетска и експресивна језичка функција запажена је у дијалозима Саве Оџачара и Вулета милиционера, док је однос моћи у дијалогу представљен кроз говор Јагоше Краја. Функција монолога исказана је кроз делање лика Теје Краја, а ефекат ћутње кроз приказ Веселе Крај и Саве Оџачара.

Наратизоване дидаскалије и коментари у тексту имају посебну стилогену вредност у драми Душана Ковачевића, те смо на репрезентативним примерима њихово деловање и објаснили, што доводи до закључка да су се поезија и проза на инвентиван начин сусрели у драми Душана Ковачевића, 
где ниједна од три стране не губи своја својства, већ бивају естетски прилагођена.

Антитетична и екстратекстуална стилистичка својства приказана су и кроз интеркултурно гледиште, стварајући ширу слику стилистичког тумачења и вредности дела. Уплив стихова, страног језика, интертекстуалности указују нам да је Клаустиробобична комеgија драма савременог доба која захтева језичко и ванјезичко тумачење како би се све вредности ваљано и сврховито препознале и анализирале.

\section{Извори:}

Ковачевић 2013: Д. Ковачевић, Драме \#3, Београд: Завод за уџбенике.

\section{Литература}

Бужињска, Марковски 2009: А. Бужињска, М. П. Марковски, Кюижевне тиеорије XX века, Београд: Службени гласник.

Живковић 2011: Д. Живковић, Метатеатралност и критика друштва у Клаустрофобичној комедији Душана Ковачевића,

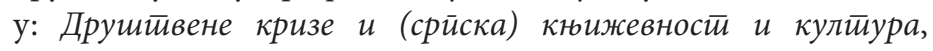
Крагујевац: Филолошко-уметнички факултет, 189-199.

Јакобсон 1966: R. Jakobson, Lingvistika i poetika, Beograd: Nolit.

Катнић Бакаршић 1999: Marina Katnić Bakaršić, Lingvistička stilistika, Prague, Budapest. Open Society Institute, Center for Publishing Development Electronic Publishing Program. Dostupno na: http:// inet1.ffst.hr/_download/reposi- tory/Lingvisticka_stilistika.pdf

Катнић Бакаршић 22013: Marina Katnić Bakaršić, Stilistika dramskog diskursa, Sarajevo: University Press.

Кебара 2019: Ђ. Кебара, „Црнохуморна представа деградираног друштва у комедији апсурда Душана Ковачевића”, Бања Лука: Филолої, Х, 520-537.

Киш 1978: Д. Киш, Час анайомије, Београд: Нолит.

Ковачевић 1998: М. Ковачевић, Синйакса сложене реченице у срйском језику, Београд: Рашка школа.

Ковачевић 2012: М. Ковачевић, Линіввосииллистиика кюижевног $\bar{u} е к с \bar{u} а$, Београд: Српска књижевна задруга. 


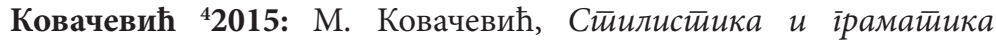
сииилских фиіиура, Београд: Јасен.

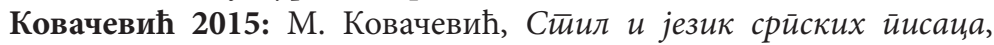
Београд: Завод за уџбенике.

Кристал 1994: D. Crystal, The Cambridge Encyclopedia of Language, Cambridge University Press.

Кузмић 2014: А. Кузмић, Слика света у драмама Душана Ковачевића, Београд: Музеј позоришне уметности.

Лангер 1981: S. Langer, „Velike dramske forme - komični ritam”, u: Miočinović, Moderna teorija drame, Beograd: Nolit.

Лончар 2017: Р. Лончар, „Антеј у ваздуху - јунак Душана Ковачевића", у: Душан Ковачевић ияеолоіија, човек, gрама (прир. Ж. Миленковић), Грачаница: Дом културе „Грачаница”, 141-164.

Лотман 1976: J. Lotman, Struktura umetničkog teksta, Beograd: Nolit.

Марјановић 22000: P. Marjanović, Srpski dramski pisci XX stoleća, Beograd: Fakultet dramskih umetnosti, Institut za pozorište, film, radio i televiziju.

Неделку 2005: O. Nedelcu, Парадигме смеха Душана Ковачевића,

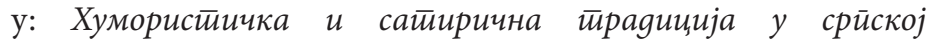
књижевностии, Београд: Научни сасиианак стависйа у Вукове gане, 35/2, 469-478.

Милосављевић 2006: Петар Милосављевић, Теорија књижевностии, Ваљево, Исток, 2006.

Мукаржовски 1986: J. Мукаржовски, Две студије о дијалогу, у:

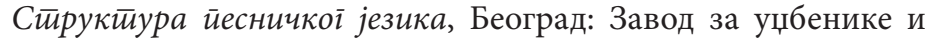
наставна средства.

Петковић 1975: Н. Петковић, Језик у књижевном gелу, Београд: Нолит.

Поповић 22010: Т. Поповић, Речник книжевних теремина, Београд: Logos Art.

Пфистер 1998: M. Pfister, Drama. Teorija i analiza. Zagreb: Hrvatski centar ITI.

Серл 1991: Dž. Serl, Govorni činovi, Beograd: Nolit.

Христић 2006: J. Христић, Есеји о gрами, Београд: Српска књижевна задруга. 


\section{Zorana Z. Ćupić}

\section{BASIC LINGUISTIC AND STYLISTIC PROCEDURES IN DRAMA CLAUSTROPHOBIC COMEDY BY DUSAN KOVACEVIC}

Using analytic sinthetic aproach stilistic manners of language will be analysed in drama Claustrophobic Comedy by Dusan Kovacevic. In order to truthfully represent language-stilistics dominants of drama this field of interests will consists of: a) question of pre registration and stilisation of functional styles, $b$ ) speach characterisations of characters on example of dramatic diskurs (dialogue, monologue, silence), c) specification of remarks, stilogenic value of narativisation in dramatic lead, d) antitetic and extratextually stylistic manners of drama Claustrophobic Comedy.

Key Words: Dušan Kovačević, Claustrophobic Comedy, drama, dialogue, lingvistic style, dramatic procedures, remarks. 